\title{
THE COUNTRY SCHOOL
}

\author{
By Harold W. Foght, \\ Professor of Rural School Education and Sociology, State Normal School, \\ Kirksville, Missouri.
}

The discussions elsewhere in this book dealing with changes in rural population, industries and life in general, make clear to the reader that American rural life has for some time been in a state of transition. The old pioneer farmer is passing away with the last of the cheap lands, and the dawn of a new era is at hand. A gradual rehabilitation is coming to life in rural districts-a life which, in many sections of our country, had become sapped of its best social satisfactions, due to the industrial call of the city and the beckoning of the last new frontier. Those who have been exploiting the soil must give way before the husbandman farmer. He is soon to possess the land. When this comes to pass, the desertion of the rural community by the people who should furnish it both intelligence and vigorous life will end.

The factors entering into the socialization of the new rural life are many. But it is safe to say that none of these is more important than the rural school. For it is school education, after all, that must furnish the leadership so essential to the solution of the rural life movement. Without strong men and women imbued with the spirit of masterful action, and thoroughly prepared for their work in the redirected rural schools, there can be no satisfactory adjustment of rural life. Let no one be misled in this matter. The present propagandist movement, directed by educators and social philosophers speaking from the rostrum in college and university, can but direct the attention of the country folk to their needs and suggest present remedies; but the ultimate readjustment will come at the hands of the new generation of scientific farmers. Here is seen the great task of the American rural school.

Any form of education, to be effective, must reflect the daily life and interests of the community employing it. With us, agriculture is the chief primary industry; consequently our rural education must be agricultural in nature. By this is meant vastly more 
than the study of agriculture as a school subject. The new school must give expression to at least two things: (I) Good, scientific farming, rendering ample returns for the labor expended; and (2) a rural social life satisfactory to those living it. This means, briefly, that farming as an occupation must be made at least as profitable as an equal investment would be in the city, or else it will be difficult to keep the best productive population on the farms. But mere commensurate returns on the money invested cannot hold them there. Daily life in the country must first be made more humanly interesting and wholesome. So long as this life is lacking in ordinary social satisfactions, people will go where they can get them. The rural school must aim to make better farmers and better helpmeets for these farmers, must make the occupation more remunerative, and the whole life more worth living and free from city domination.

There was a time when all our schools, town and country alike, had many more things in common than now. This was before steam and electric power gave us the great machine age with its greatly specialized city life. The first rural teacher was city-bred and city-trained, had city ways and sympathies, and brought with him to the country, a city course of study. But in the early days this was of little consequence; since even city life, so called theil, was provincial in nature, in many ways scarcely more than an overgrown rural life. But times have changed. Our towns have become mighty centers of commerce and manufacture. The needs of city life have found expression in a course of study preparing children for the varied activities there, and all has gone well with the city. But what about the rural schools? They have gone right on, down to the opening of the present century, using a course of study formulated for children with city motives, with the natural result that vast numbers of farm boys and girls have been trained away from the country instead of for it.

The specific charge against the rural school is this: (1) It has drawn too much of its substance from sources foreign to rural needs; and (2) it has failed in other ways to keep pace with the demands of our rapidly developing agricultural life. The school has had its face towards the city. Much more, it has long been almost at a standstill. Says Mr. Roosevelt's Commission on Country Life: "The schools are held largely responsible for ineffective farming, 
lack of ideals, and the drift to town. This is not because the rural schools, as a whole, are declining, but because they are in a state of arrested development and have not yet put themselves in consonance with all the recently changed conditions of life." The great task is to put the school in harmony with the needs, and time and place of present-day life.

Before the rural school can become rooted to the soil as the chief agency in this social-economic reconstruction, several important changes must be brought about. Chief among these may be named: (I) A thorough redirection of the subject-matter taught in the schools; (2) a general reorganization of the entire working staff of administrators, supervisors and instructors; and (3) the re-building, at liberal cost, of the entire school plant.

(I) Of first concern is the subject-matter taught in the school. The universal elements are naturally the same whether given in the country or the city. ${ }^{1}$ In locality interests only is there great divergence. Country children are reared in their own peculiar environment. They find their consuming interests in field and meadow, in orchard and garden, and if led by teachers sufficiently prepared in rural education, will early grow up in love with nature for its own sake, as also with the farm and farm home, there to become content to live out their free and independent and wholesome lives.

Some of the subjects which have long held place in the traditional farm-school curriculum are fast yielding this place, having failed to express the activities and needs of the community. Or, at least, such subjects are now receiving an altered emphasis. New subjects of vital importance to rural progress are finding prominent places in the new course of study. Thus, nature study, elementary agriculture, manual training and domestic science, farm accounting, physical education, etc., are beginning to play an important part in the life of many progressive schools. Nature study must be considered a substantial background for the whole scheme of farm education. Agriculture develops as a concrete expression of the practical side of farm life. Manual training and domestic science teach an added dignity in household tasks, making these less arduous and giving a new and broader outlook on life.

1 The several paragraphs dealing with the curriculum are reproduced in substance from a chapter on The Community and the Curriculum, prepared by the author for a book entitled Educational Backgrounds in Rural and Village com. munities, under the editorship of Professor Joseph K. Hart, of the University of Washington. 
In the main, however, the process of redirection is not so much one of adding new subjects to the curriculum as of putting a new leaven into the old essentials. Nature study, for example, may be taught at odd moments in an informal way from the first year to the time of beginning concrete agriculture, as a leaven in all the subjects. Lessons in literature and composition may very properly emphasize the beauties of nature in the farm environment. Geography and arithmetic, likewise, can make use of much that is near at hand and applicable to daily life. These schools are already teaching less of stocks and bonds, cube root and Troy weight, and more of dairy problems and rotation of farm crops, spraying mixtures and handy farm measures. When the average rural school shall have got the great vision and have redirected its work into these channels, the new educated leadership, spoken of above, will readily be realized.

(2) The rural schools as now commonly organized are wholly incapable of providing our farm population with the very vital subject matter indicated above. The units of organization are mostly too large or too small, thereby offering an inadequate basis for school administration. The latter is in the hands of untrained and generally incompetent school boards. Finally, the men and women that supervise and teach the schools lack, in large measure, the vision and preparation necessary to overcome this retarded state.

The units of organization commonly employed are, district, township and county. ${ }^{2}$ Of these the district unit is the smallest and most democratic; but, unfortunately, it has passed its day of greatest usefulness. Organized as a necessity in colonial New England it was later carried by the pioneer settlers to the Middle West and West. This unit has proved too small to be entrusted with final legislation in matters of importance. Especially is this true where the taxing power is concerned. Local jealousy, parsimony and individual indifference have contributed much toward making the district unsatisfactory in actual practice. Under existing conditions it is quite possible for two or three individuals to dictate or manipulate the policy of the district. This is dangerous, to say the least, and explains in large measure why great sections of the country still cling to their thousands of poorly maintained, weak and wholly inadequate schools.

2 See The American Rural School, Ch. II, The Macmillan Company. 
There are several contributory causes for this gradual decadence of the district unit. The unrest in rural communities, with its exodus to town or to the western frontier, has done destructive work. To this should be added the pernicious custom of dividing and subdividing districts-still going on in the Middle West and West-already weak in the extreme, to the end of giving every ambitious farmer a schoolhouse near his own farmyard. Educational effort must from this time onward be exerted to combine these small units into areas large enough to maintain twentieth century schools. The day of the little red schoolhouse lies behind us.

The township (town) system of organization is rapidly displacing, or at least modifying, the small district in those sections of the country where the township is used for the administration of local government. In the South where the county is the basis of government, the same is used for educational purposes also. Where one board, elected from the area at large, controls all the schools, whether such unit be township or county, a more uniform standard of excellence and equality of school provision is sure to prevail. The county unit is believed by some to be too large for practical purposes. This may or may not be true. Certainly this policy is bringing excellent results in parts of the South where county organization has hastened consolidation of weak schools. Legislative and other aid should be invoked to hasten the day of transformation from the district unit to either the township or county or other large unit of organization. There cannot be a strong school nor much community spirit and enterprise before this occurs.

A great menace of the rural school is found in the general weakness and even incompetence of the school board. Very few country-bred persons have had adequate educational advantages to appreciate the needs of the schools. This becomes a further argument in favor of large units of organization; for, surely, the larger the area of the district the greater the chance of finding competent men. Under the circumstances many a board is composed of honest, well-meaning, but ignorant and, therefore, inefficient men, whose work is often further weakened by the addition of some aggressive, self-opinionated individual with an axe to grind.

If many of the best men in the community cannot be induced to serve on the school board, and this is a lamentable fact, the state should assist in every possible way those who are willing to 
give their time to the community. Let them be trained for school service. We train teachers, why not also the men who hold the educational policy of the community in their hands? The monthly teachers' meetings and annual institute have played an important part in teacher-training. As much at least could be done for our school boards. They might by law be required to attend certain stated meetings to listen to specialists on school administration and through informal discussion at these meetings get expert knowledge for their important office. The state should provide mileage and liberal per diem pay for attendance upon all such meetings.

Next to be considered are the school overseers, commonly known as county or township superintendents or, in a few places, school commissioners. These officials, even more than the school boards, are in a position to mold the educational policy of the open country. But for many reasons they have not been equal to the task.

At this juncture let us recall that the early New England "school committees" had duties both of an administrative and supervisory nature. In time, as their tasks became multiplied and complex, the unsalaried committee found it necessary to delegate its supervisory powers to a paid superintendent, retaining only the administrative powers. Thus came into existence a school expert who, in our city schools is the center of the whole system-a man who outlines and carries into execution the educational and much of the business policy. Professional prestige and fair compensation have held strong educational talent in the city schools. But the rural schools have fared ill. They have been given over to a haphazard supervision that is usually underpaid and often both unskilled and inefficient. These pages do not permit of a rehearsal of the many more or less self-evident causes leading to present conditions. A word as to remedies must suffice. ${ }^{3}$ To begin with, the size of the supervision unit has caused much trouble. In New England it was at first limited to the small district, and this, of course, could not afford adequate paid supervision. Since 1888 , however, legislative enactments have provided for the union of two or more districts into "union districts," under which several townships may be placed under one competent supervisor. This system has recently been extended to several states of the Middle West which are under township organization, and works well.

\footnotetext{
'See The American Rural School, Ch. IV.
} 
The chief difficulty is encountered, however, in the many states making use of the county superintendency. Here the unit of supervision is invariably so large that close and effective supervision is out of the question, if the work is left for one man to perform. Several remedies are at hand. One is to furnish the superintendent with competent office help, that he may spend practically all his time in the field; another, is to subdivide the county into two or more supervision districts, each under deputies responsible to the county superintendent. Such remedies are feasible and where tried have led to greatly improved supervision.

In addition to the above, the superintendency cannot be put on a true professional basis before the office is everywhere removed from party politics. So long as it is political many of the best teachers will not contest for the office. In states where the merit system prevails, and these are on the increase, the quality of supervision is rapidly improving. The superintendent's qualifications for office, too, should receive much more consideration than has been the case in the past. The man who supervises the schools should at least have as good an academic and professional preparation as the average teacher working under him. This is seldom the case.

The last member of the working staff to receive consideration in this discussion is the teacher. On him, after all, the greatest responsibility must rest. The new leadership needed in country districts cannot be forthcoming if the teacher is lacking in vision and power. The school now requires at least these things of the teacher: ( I) He must be strong enough to establish himself as a leader in the community where he lives and labors; (2) he must have a good grasp on the organization and management of the new kind of farm school; and (3) he must show expert ability in dealing with the redirected school curriculum.

Here is the real problem of the rural school. We have very few teachers prepared for this work. The average teacher is city trained and knows little about the actual needs of country life. Indeed, it has been the belief for a long time that the rural teacher needs no special training at all. It is even argued "that a good teacher will teach any school well and there should be no differentiation." Such views are no longer tenable. A good academic preparation is necessary; but it does not immediately prepare the teacher to understand and meet the many baffling problems which belong to the revitalized rural community. 
The teachers who have in hand the twelve million rural boys and girls are practically unprepared to meet the new difficulties. Here is a monumental task calling for solution. The agricultural colleges and normal schools have for some time been emphasizing agriculture and domestic science, and a limited number of teachers in these subjects have gone forth into the field. But, upon the whole, very few teachers of a "rural mind" have found their way to the country from these schools as yet. City and town higin schools in half a dozen states have established normal departments or training classes to supply the demand for professionally prepared rural teachers. The only unfortunate thing about the whole matter is, that these training schools are at urban centers; and particularly, they find it hard to get the right point of view because they are more or less "city minded." Wisconsin attempts to overcome this difficulty in its county training schools, so-called. These strive to prepare youth from the farm to return to the farm as teachers. Present indications are, however, that the many state normal schools all over the country will organize departments for the training of teachers in rural life and problems, the new school organization, as well as in the redirected school curriculum. To the writer's knowledge at least a score of normal schools have or are organizing such departments.

(3) Hand in hand with teaching the subjects essential to farm life and a reorganized working staff to look after this teaching must develop an adequate modern school plant. Let us remember, the school is a farm school. It must be built for this purpose, in ample grounds-nature's own laboratory. It must be sanitary and well adapted to the new kind of teaching, be attractive and so large and centrally located as to become from the first the natural community center.

It is really needless to state here that in an architectural way the rural school has not kept abreast of the march in civilization. While well-equipped modern buildings are beginning to appear here and there, the schoolhouse is yet, with very few exceptions, the proverbial box car type so familiar to us all. No description is necessary here of its faulty lighting and ventilation, and utter lack of every sanitary appliance. Let it suffice to state that we cannot expect much in the way of community idealism to come from such ugly, uninviting structures, wind-swept and forlorn, set in some fence corner and exposed to summer sun and winter blast. 
In communities where we must get along with the one-teacher schoolhouse for years to come, we should, by law, insist that where new houses are built or old ones reconstructed, such construction shall not begin until the plans and specifications have been accepted by a competent board appointed for that purpose. It should also be incumbent on the state superintendent of public instruction to publish a pamphlet on school architecture and place the same in the hands of all school officers, with all necessary recommendations and directions.

But the small school, make it as efficient as one will, cannot furnish the largest measure of educated leadership, such as is now sought. The slogan of our day is to re-establish the ancient principle of "equal rights to all," by offering in the country for country children as complete an education as is being offered in the city for city children. This contemplates the construction, here and there where needed, of schools having eight grades of work together with complete high school courses. The several small schools of a given community are to be consolidated into one strong central school plant, set in a large area of five to twenty acres, having its own garden, experiment plots, etc.

The new school will do for the community what the old was incapable of doing. It may be expected to train the boys to become scientific farmers and the girls practical farmers' helpmeets. It will inculcate a wholesome love for country life, and may be expected, accordingly, to counteract the townward exodus. But more: From the school will come the impulses to organize the rural population on a more permanent social and economic basis. It will become the center of all community interest. Here the extension lecture course may be held; here the neighborhood social entertainments and farmers' institutes and corn growing and cooking contests.

In a word, all that has been said above means that if the American rural school is to be the vital factor that it should be in the reconstruction of our rural life, the school must quit "marking time"; it must become more virile, more aggressive, and respond to the needs of present-day rural civilization. 